\title{
ALABAMA DISTRICT FLOOD PLAN
}

By T.S. Hedgecock, J.L. Pearman, and V.E. Stricklin

U.S. GEOLOGICAL SURVEY

Open-File Report 02-304

Montgomery, Alabama

2002 


\section{U.S. DEPARTMENT OF THE INTERIOR}

GALE A. NORTON, Secretary

\section{U.S. GEOLOGICAL SURVEY}

CHARLES G. GROAT, Director

For additional information, contact:

District Chief

U.S. Geological Survey 2350 Fairlane Drive, Suite 120 Montgomery, AL 36116
Copies of this report can be purchased from:

U.S. Geological Survey

Information Services

Box 25286, Federal Center

Denver, CO 80225 


\section{CONTENTS}

Introduction. Page
Flood personnel
Communications
Data Nents
Procedures
Post-flood operations
Rafety
Travel
Data collection

\section{Appendix 1}

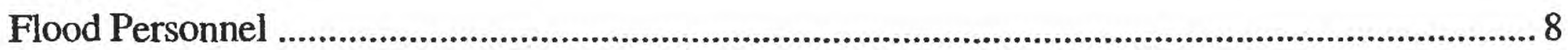

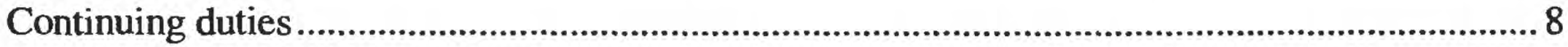

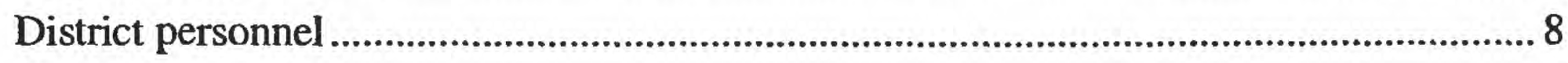

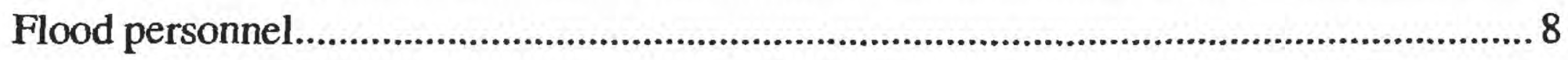

Montgomery and Tuscaloosa Flood Coordinators............................................................

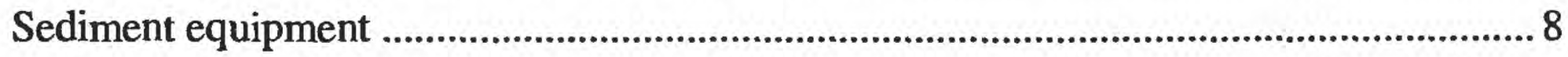

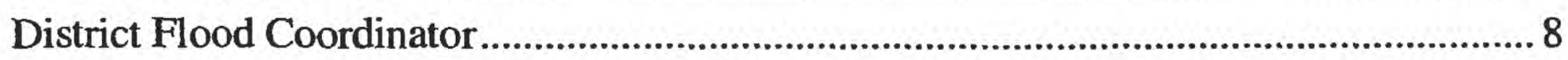

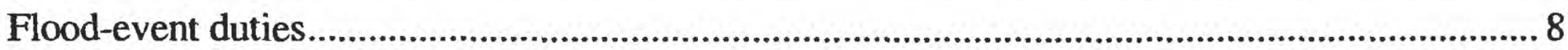

Flood Coordinator

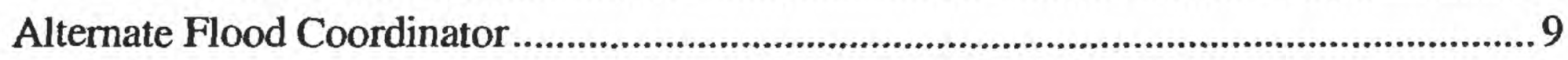

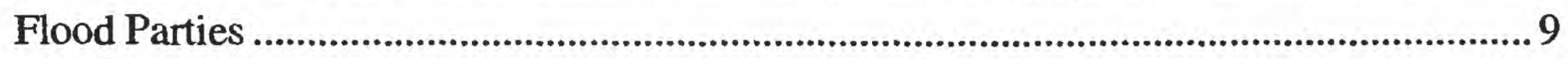




\section{Appendix 2}

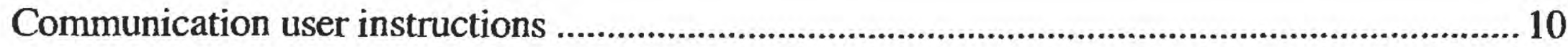

Alabama District Personnel Directory ......................................................................... 10

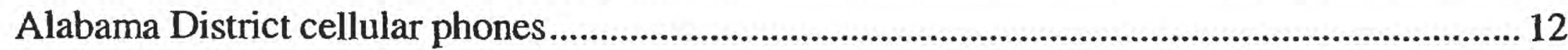

District office pool cellular phones................................................................................ 12

Streamflow stations with telephone modems ................................................................ 12

Streamflow stations with satellite telemetry ................................................................ 13

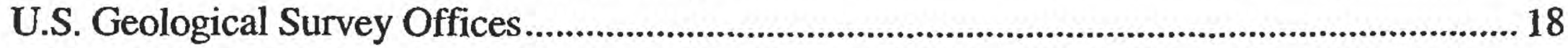

National Oceanic and Atmospheric Administration ............................................................19

Weather Service Forecast offices....................................................................... 19

Southeast River Forecast centers ....................................................................... 19

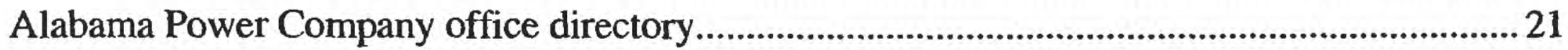

U.S. Army Corps of Engineers office directory .................................................................2 21

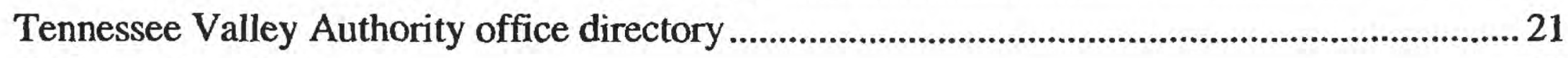

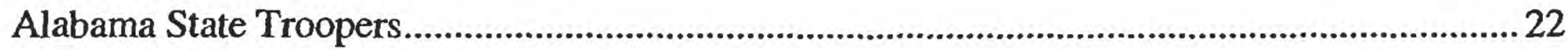

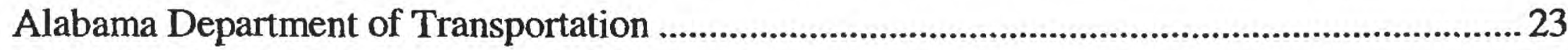

Project Alert (WRD Memorandum No. 90.22) …..............................................................25

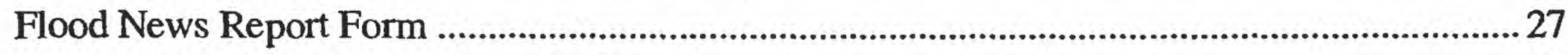

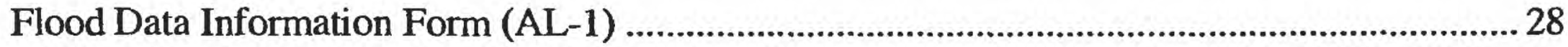

\section{Appendix 3}

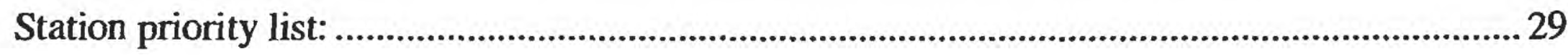

\section{Appendix 4}

Special problems in conventional current-meter measurements:

Measurement of deep, swift streams.

\section{Appendix 5}

Equipment Requirements 
Acronyms and abbreviations:

$\begin{array}{ll}\text { ADCP } & \text { Acoustic Doppler Current Profiler } \\ \text { DOT } & \text { Department of Transportation } \\ \text { FCC } & \text { Federal Calling Card } \\ \text { FEMA } & \text { Federal Emergency Management Agency } \\ \text { GH } & \text { Gage height } \\ \text { GSA } & \text { General Services Administration } \\ \text { NOAA } & \text { National Oceanic and Atmospheric Administration } \\ \text { Q } & \text { Discharge } \\ \text { SW } & \text { Surface water } \\ \text { TVA } & \text { Tennessee Valley Authority } \\ \text { TWRI } & \text { Techniques of Water Resources Investigations } \\ \text { USGS } & \text { U.S. Geological Survey } \\ \text { WRD } & \text { Water Resources Division }\end{array}$

The use of firm, trade, and brand names in this report is for identification purposes only and does not constitute endorsement by the U.S. Geological Survey. 


\title{
ALABAMA DISTRICT FLOOD PLAN
}

\author{
By T.S. Hedgecock, J.L. Pearman, and V.E. Stricklin
}

\section{INTRODUCTION}

The purpose of this flood plan is to outline and record advance planning for flood emergencies, so that all personnel will know the general plan and have a ready-reference for necessary information. This will ensure that during any flood event, regardless of the extent or magnitude, the resources of the District can be mobilized into a maximum data collection operation with a minimum of effort.

District streamflow gaging station operations generally are conducted from two offices: the District Office in Montgomery and the Field Office in Tuscaloosa. The following persons are designated as flood activity coordinators for these offices: Montgomery, James L. Pearman; Tuscaloosa, Victor E. Stricklin. During localized or routine flood events, field personnel assignments will be made independently by the District or Subdistrict Coordinator. When flood activities require the presence of these persons in the field, personnel assignments will be made by the alternate District Flood Coordinator, T.S. Hedgecock. If district or subdistrict personnel cannot adequately monitor a flood, the District Flood Coordinator assigns additional support personnel, as outlined in this plan or as modified for the existing situation.

The flood plan will be updated as required due to changes in personnel, site conditions, and by additional data acquisition.

\section{FLOOD PERSONNEL}

The flood personnel assignments and individual duties are described in Appendix A and $B$ of this District Flood Plan.

\section{COMMUNICATIONS}

During flood emergencies, good communication is very important and the telephone will be the primary means of communication. Field personnel will frequently place long-distance calls, and district cellular phones will be used. Each vehicle should be equipped with a cellular phone that has been assigned to a specific individual or checked out from the office pool. Additionally, each person has a Federal Calling Card (FCC) with user instructions printed on the back. The FCC will be used to place FTS 2000 off-net calls. FCC user instructions are included in Appendix B, which also contains a list of telephone numbers to assist in maintaining good communications during flood emergencies. The list includes numbers for Alabama District personnel, cellular phones, streamflow stations and for the following offices: Water Resources Division (WRD), National Oceanic and Atmospheric Administration (NOAA), Alabama Power Company, U.S. Army Corps of Engineers, and Tennessee Valley Authority (TVA).

Flood personnel will contact the Flood Coordinator upon completion of assignments and give the following information for each station visited:

- gage height

- time

- rate of change of stage

- Q measurement information (GH and Q, if computed)

- time of peak (if applicable)

- weather and road conditions

- other significant information 
A District form, AL- 1 (see Appendix B), has been prepared to assist in the compilation of this information. Field personnel will make additional telephone contacts at any time actual field conditions are found to be significantly different from expectations.

Communications with adjacent WRD Districts and with other Federal, State, and municipal agencies will generally be made by the Flood Coordinator. For extraordinary floods, requests for additional personnel and equipment will be made by the District Chief.

Liaison with Division and Regional Headquarters is the responsibility of the District Surface-Water Specialist or other appropriate District personnel. Communications will follow the instructions in WRD Memorandum 90.22 (dated August 25, 1992) and the updated Project Alert section of this document included in Appendix B.

\section{EQUIPMENT}

A complete set of flood-measuring equipment will be maintained for each regularly assigned vehicle. Sets of emergency equipment will also be maintained for use during extreme flood events when other vehicles must be obtained. Additional vehicles can be obtained on dispatch from the General Services Administration (GSA) Motor Pool or from commercial rental companies if the GSA is unable to meet our needs.

An adequate supply of sediment samplers and bottles will be maintained for use during extreme flood events. Sediment samplers available in the District are of two categories: (1) suspended and (2) bed material. The DH59 and DH-76 suspended-sediment samplers are the ones routinely used to obtain depthintegrated sediment samples at miscellaneous sites and streamflow gaging stations, as assigned. Other types of suspended-sediment samplers, P-61 and D-49, are assigned to field parties with specific event sampling assignments as indicated by the footnotes to
"Flood Personnel" in Appendix A. Bed material samplers, BM-54 and BMH-60, are also assigned to field parties with specific event sampling assignments as indicated in Appendix A. Bed material samples generally will not be taken during flood events, but, if required, will be at the direction of the Data Section Chief through the Flood Coordinator.

Individual responsibilities of the flood personnel for equipment maintenance are delegated in the "Duties" section of Appendix A.

\section{DATA NEEDS}

A complete list of sites where flood data are collected and the data needs for each site are listed in Appendix C. Each site is assigned a priority based on data needs and the hydrologic characteristics of the site.

\section{PROCEDURES}

The procedures as outlined in Techniques of Water-Resources Investigations (TWRI) manuals and Water-Supply Paper 2175, Measurement and Computation of Streamflow: Volume 1. Measurement of Stage and Discharge will be followed in collecting streamflow data during floods. Each field person should be familiar with Appendix D, which contains information concerning special problems encountered in conventional currentmeter measurements and procedures to follow when obtaining miscellaneous or periodic sediment samples at regular streamflow stations during floods. When practical, field personnel will take or obtain photographs showing unusual flood conditions.

\section{AERIAL PHOTOGRAPHS}

Federal Emergency Management Agency (FEMA) flood maps and other maps, such as U.S. Geological Survey (USGS) flood prone maps and USGS topographic maps will be used to delineate segments of streams where aerial photographs are desired during, or immediately following, extensive floods. 
These maps will be utilized for planning and executing photography flights.

\section{POST-FLOOD OPERATIONS}

Data obtained during the flood will be evaluated to determine what data needs were met and what new needs have arisen. This will be done quickly so that follow-up measurements can be made where necessary. Crest stages will be examined to determine sites where indirect measurements should be made, and marking of high-water marks for indirect measurements can be done. Upon completion of follow-up operations, the listing of data needs will be examined and priorities will be reassigned where necessary.

The Flood Coordinator will debrief field personnel to obtain qualitative information such as location of inundated roads, observed damage, and photographs.

\section{SAFETY}

Job safety is no more important during flood events than during routine field operations, but there is likely to be more potential for the occurrence of dangerous situations during flood events. These situations may include any or all of the following conditions: swollen streams with swift velocities; turbulent flow; heavy debris; poor visibility; inclement weather; darkness; heavy traffic; wet, slippery roads; or even damaged road surfaces and bridge structures. The personal protective equipment and safety supplies provided to everyone, and safety equipment placed in vehicles for routine data collection activities will generally be sufficient for operations during flood events. The objective of field operations during and following flood events is to safely collect hydrologic data in order to document certain occurrences related to individual flood events. These occurrences include the following: gage height and stream-discharge relation, including peaks; gage height and sediment-discharge relations; and chemical-quality of floodwaters at specific times. During flood events, data will be obtained by flood parties as assigned.

\section{Flood Parties}

Generally, though not always, a flood party will consist of two or more persons. The additional person(s) will provide necessary assistance required for field operations during floods, including improved measures of safety.

\section{Communications}

During flood operations the level of communication between the field and office will increase significantly due to the nature of the activity. In addition to communication dictated by daily activities, each flood party is required to communicate with the flood coordinator or his designate at the end of each workday. The contact can be as late as arrival at the motel, office, or home, but should be no earlier than the completion of work at the last site. Concerning this requirement, the flood party and flood coordinator, by mutual agreement, can make other arrangements during the course of daily activities. To assist with the increased level of communication, radio and cellular phones are available. Cellular phones can be used to improve response-time during medical and other emergencies and each flood-party member should be familiar with the use of these phones. Should cellular phones not be available for all flood parties, one-person parties, if there are any, will be given priority. For a listing of radio and cellular phone assignments and related information, see Appendix B. During flood events, adjustments in phone assignments will be made by the flood coordinator or his designate.

\section{Travel}

Travel is a necessary part of field activity, and routinely may be the most dangerous component of our work schedule. During and following serious flood events, routine hazards of travel may be accompanied by hazardous conditions. These can include any and all of 
the following: wet, slippery road surfaces; poor visibility as a result of inclement weather, sunrise, sunset, or darkness of night; roads and bridges inundated by flood waters, or damaged from previous floodwater inundation; roads and bridges obstructed by debris from winds and/or floodwaters; and other vehicles. You should be alert for the existence or possible occurrence of any of these conditions. A reasonable response may be to drive slower and more defensively, remembering that other drivers are subjected to the same conditions and their failures may endanger you. It is important that your driving be tailored to fit the conditions. During floods, additional sounding weights may become part of the equipment for individual vehicles. It is important that these weights be properly secured during travel.

\section{Data Collection}

During floods, streamflow measurements, water-quality samples and sediment samples can be obtained by persons from boats, bridges and cableways; the same as during routine operations. However, the presence of certain conditions can make data collection inherently more dangerous during floods, and flood parties must always be conscious of the existence or possibility of occurrence of these conditions. Activities from boats, bridges, and cableways are all affected by the following conditions: high stream stage; fast velocity; turbulent flow; and debris, including large trees. Large debris is likely the most dangerous hazard and every effort should be made to avoid contact with it because of uncertainty of its size since only a small portion of the material may be exposed. However, the possibility always exists that suspended measuring or sampling equipment may become entangled with debris, especially trees. All reels should be equipped with break-away cables, and the flood crew should always have wire-cutters available for immediate use to cut the suspension cable if necessary. CUTTING
A CABLE IS DANGEROUS. If you cut a cable, you must be prepared for serious recoil of booms, bases and other pieces of equipment. Cutting a cable when working in a cablecar is especially dangerous. You must be prepared to prevent yourself from being launched like a missile as car returns toward its normal position. Be sure other pieces of equipment are secured, especially the car puller.

When working from a bridge, the crew must be alert to the possibility that bridge abutments may wash-out, or that the structure itself may be washed away. Careful inspection and continuing observation generally will indicate that destruction is occurring. If serious scouring at an abutment(s) becomes obvious, you probably should get off of the bridge. In Alabama during flooding, it is standard operating procedure for the Department of Transportation (DOT) to deny access to bridges when water is on the "low steel", even if there is no evidence of bridge failure. If there is no evidence of bridge damage or failure, and you are certain that the structure is safe, you may have to exert considerable effort to obtain permission to get onto the bridge. It will very likely require approval from the supervisor of the DOT personnel on the site. If you are allowed to work on a bridge closed to the public, traffic is not a problem. However, for a bridge which is open for travel, traffic will be a problem. Inclement weather, poor visibility, and increased volume of traffic may all combine to increase the seriousness of the traffic problem. Traffic volume may increase simply because of human curiosity. There will be many persons crossing the stream just to see what the flood looks like, and the really curious ones will stop to find out what you are doing. You must immediately insist that for the safety of everyone, they should quickly move along. If possible, this should be done courteously; but "whatever it takes". 
For dealing with traffic on bridges, there are numerous items available including vehicle flashers and additional emergency flashers, cones, signs, flags, flagmen, and reflective vests. USE THEM! In addition, there may be local law enforcement personnel available for assistance. These include city and county police, the county sheriff, and the Alabama Highway Patrol. They are usually willing to provide traffic control during flood work. The blue flashing lights on their vehicles get the attention of others. The DOT should also aid in traffic control.

In the Alabama District, boats are generally not used during severe flooding for making conventional streamflow measurements. However, sediment and water-quality samples are routinely collected using boats on the larger rivers in Alabama, such as the Alabama River and Tombigbee River. Boats are used during flooding to access gaging stations and for other transportation as required. Whether used for data collection or simply for transportation, the operators and occupants of boats must be cognizant of the additional dangers of greater depths, higher velocities, turbulent flow, and floating debris present during flood events. During severe flooding, the Alabama District has the capability to obtain streamflow measurements via a boat-mounted Acoustic Doppler Current Profiler (ADCP). The crew for this activity generally consists of three persons; a boat operator, a ADCP operator, and a "spotter". The "spotter" is responsible for watching for floating debris in the channels and for submerged stumps, trees, and other hazards in the overbank sections. The three-person crew seems reasonable and the Alabama District has adopted it as standard operating procedure when using the ADCP during floods.

If used appropriately, personal protective equipment and boat-safety equipment which are routinely provided are sufficient for survival should an accident occur. The appropriate use of your life vest or floater coat is to wear it on your body.

If during normal operations you make proper use of the safety materials, supplies and equipment provided to you and you perform your duties in a safe manner, then safety, relative to flood work, will be just another day in the field. However, you should be aware of conditions that may make field work during floods inherently more dangerous than on routine occasions. Occasional reading of the safety section of this flood plan can assist you in recognizing these conditions and provide a framework for action when they occur. 


\section{REFERENCES}

Atkins, J.B., 1996, Magnitude and frequency of floods: U.S. Geological Survey WaterResources Investigations Report 95-1499.

Buchanan, T.J., and Somers, WP., 1969, Discharge measurements at gaging stations: U.S. Geological Survey Techniques of Water-Resources Investigations, book 3, chap. A8.

Rantz, S.E., and others, 1982, Measurements and computation of streamflow, volumes 1 and 2: U.S. Geological Survey WaterSupply Paper 2175, 631 p. 


\section{Appendixes}




\section{ALABAMA DISTRICT FLOOD PLAN - Appendix 1}

\section{FLOOD PERSONNEL}

Personnel will be assigned to field parties and geographic areas as required to cover the magnitude of the flood event. Assignments will be made by the Flood Coordinator, James L. Pearman or Alternate Flood Coordinator, T.S. Hedgecock.

\section{CONTINUING DUTIES}

\section{District Personnel:}

During potential flood periods, those who routinely make data-collection field trips of 3 days or more in length will:

(1) prior to departure, obtain some information concerning the long-range weather forecast,

(2) as dictated by the weather forecast, make contact with the district or subdistrict supervisory personnel on day 2 of the trip; additional contacts at the direction of appropriate personnel, and

(3) communicate immediately to the Flood Coordinator all rainfall and stage information that would be helpful in determining the extent and magnitude of possible flooding.

It shall be the responsibility of all personnel to communicate to the Flood Coordinator, immediately from the field, all information relative to flooding.

\section{Flood Personnel:}

Flood party chiefs and individuals with specific flood-event assignments will maintain data collection equipment to be used by them during flooding. The equipment is to include a briefcase containing items such as stop watches, earphones, a steel tape, a tape weight, a flashlight, a calculator, current meter rating tables, a note pad, paper, forms (such as measurement notes and inspection forms), pencils/pens, a copy of Water-Supply Paper 2175, the Alabama District Flood Plan, the latest publication of Water Resources Data for
Alabama, and WRIR 95-4199 (latest floodfrequency reports).

\section{Montgomery and Tuscaloosa Flood Coordinators:}

Montgomery and Tuscaloosa Flood Coordinators furnish to the District Flood Coordinator the information necessary to maintain the lists of gaging station and creststage gage measurement needs. They will also see that field crews maintain streamflowmeasuring equipment according to Flood Plan instructions.

\section{Sediment Equipment:}

The Montgomery and Tuscaloosa data sections are currently responsible for maintaining an adequate supply of operable suspended and bed-material sediment samplers and related equipment as prescribed by the Flood Plan, ensuring appropriate distribution among Field Headquarters. However, at the current time there is no funding for collection of samples.

\section{District Flood Coordinator:}

The District Flood Coordinator is responsible for ensuring that:

(1) all flood plan appendices are current,

(2) appropriate personnel are familiar with the flood plan, and

(3) personnel with specific continuing duties are meeting their responsibilities.

\section{FLOOD-EVENT DUTIES}

\section{Flood Coordinator:}

The flood coordinator will use all available sources of rainfall and flow information to determine the extent and magnitude of flooding; assign personnel based on initial evaluation of the situation; examine data and other reports as received from the field and modify initial assignments and/or make additional assignments when necessary. Throughout the flood, the coordinator will maintain communications with adjacent 
Districts and other Federal, State, and municipal agencies and advise the District staff of existing and forecasted flood conditions. The coordinator will continue to direct activities during follow-up operations until the level of work has returned to normal.

\section{Alternate Flood Coordinator:}

The Alternate Flood Coordinator will assist the District Flood Coordinator, act as District Flood Coordinator, or perform other duties as may be required.

\section{Flood Parties:}

Collect data as directed by the Flood Coordinator or alternate, and maintain communications according to Flood Plan instructions. 


\section{ALABAMA DISTRICT FLOOD PLAN - Appendix 2}

\section{COMMUNICATION USER INSTRUCTION}

The most common calls by field personnel will be made from Southern Linc radio/phones that have been assigned to each individual. FTS 2001 can be accessed by off-net dialing from commercial stations (pay phones), using MCI calling cards that have been issued to each employee.

\section{ALABAMA DISTRICT PERSONNEL}

Brian Atkins

3105 Fernway Court

Montgomery, AL 36111

(334) 262-3542

(334) 235-1112 (cell)

Doug Batemon

1012 Commercial Street

Hanceville, AL 35077

(205) 287-2828

(205) 361-4940 (SL)

Danny Berlin

P.O. Box 237

Coosada, AL 36020

(334) 285-7954

(334) 850-1015 (SL)

Bobby Brendlinger

1514 9th Street

Tuscaloosa, Al 35401

(205) 248-6536

(205) 361-3692 (SL)

Athena Clark

1818 Beauvoir Lake Drive

Montgomery, AL 36117

(334) 272-9201

(334) 590-5248 (cell)

Mark Dickman

5 Lily Pad Circle

Millbrook, AL 36054

(334) 285-2930

(334) 850-0933 (SL)
Paula Dye

3604 Lazy Brook Lane

Montgomery, AL 36116

(334) 213-7370

(334) 324-2865 (cell)

Marty Fondren

1637 Mallard Circle

Tuscaloosa, AL 35405

(205) 752-3729

(205) 361-1660 (SL)

Amy Gill

4505 Beth Manor Drive, Apt C

Montgomery, AL 36109

(334) 277-2914

Katie Green

4477 Lee Road \#137, lot 48

Auburn, AL 36832

(334) 466-0237

Bill Hard

114 Arcadia Drive

Tuscaloosa, AL 35405

(205) 633-0909

(205) 361-1661 (SL)

Susan Hartley

1251 S. Hull Street

Montgomery, AL 36104

(334) 834-0704

(334) 850-0995 (SL)

Scott Hedgecock

106 Lina Drive

Prattville, AL 36067

(334) 365-7869

(334) 850-0975 (SL)

Brett Johnston

P.O. Box 156

Verbena, AL 36091

(205) 755-4345

(205) 850-0981 (SL) 
Kristin Justice

3671 Balm Road

Wetumpka, AL 36092

(334) 567-6779

Kevin Kelly

2222 Hwy 143

Elmore, AL 36025

(no phone \#)

(334) 850-0984 (SL)

Bob Kidd

14704 Pine Circle

Coker, AL 35452

(205) 339-9044

(205) 361-1662 (SL)

Darrell Lambeth

609 South Capitol Parkway.

Montgomery, AL 36107

(334) 832-9464

(334) 850-0985 (SL)

Ann McPherson

P.O. Box 231353

Montgomery, AL 36123

(334) 613-1030

(334) 850-0990 (SL)

Will Mooty

619 Lockwood Street

Auburn, Al 36380

(334) 887-3251

(334) 850-0991 (SL)
Richard Moreland

542 Clayton Street

Montgomery, AL 36104

(334) 265-1693

(334) 850-0992 (SL)

Leroy Pearman

954 Silver Creek Circle

Prattville, AL 36066

(334) 361-7940

(334) 850-0993 (SL)

Bill Psinakis

4316 Florence Street

Montgomery, AL 36109

(334) 270-1378

(334) 850-3092 (SL)

Tyler Sansing 13675 Belaire Estates

Coker, AL 35452

(205) 339-8941

Michelle Smith

5104 29th Street

Tuscaloosa, Al 35401

(205) 333-9070

(205) 792-9592 (cell)

(205) 361-1767 (SL)

Vic Stricklin

336 Revere Road

Tuscaloosa, AL 35405

(205) 366-0709

(205) 886-1112 (C)

(205) 361-1663 (SL) 


\section{ALABAMA DISTRICT CELLULAR PHONES}

The District has several cellular phones and all Flood Parties will have a cellular phone, if possible. Most individuals have a radio/phone (numbers provided on previous page). If there is a shortage of phones, more Flood Parties than phones, oneperson Parties will have phone-possession priority over multi-person parties. Some cellular phones are assigned to specific individuals and others are maintained in a District Office Pool. It shall be the responsibility of each Flood Party to inform the Flood Coordinator of the phone in its possession. An individual with a permanent assignment will not be required to communicate with the Flood Coordinator unless no one in his Flood Party has a permanently assigned phone.

\section{DISTRICT OFFICE POOL CELLULAR PHONES}

\author{
(334) 399-4656 (Montgomery) \\ (205) 799-6669 (Tuscaloosa)
}

\section{STREAMFLOW STATIONS WITH TELEPHONE MODEMS}

02361000 - Choctawhatchee River near Newton ............ (334) 299-6320

02363000 - Pea River near Ariton ................ (334) 762-3002

02364000 - Pea River at Elba ................... (334) 897-8359

02423000 - Alabama River at Selma ................. (334) 872-9209

02423425 - Cahaba River near Cahaba Height ............ (205) 991-3357

02453500 - Mulberry Fork at Cordova................ (205) 483-7081

02458450 - Village Creek at Avenue W at Ensley........... (205) 786-0309

02462500 - Black Warrior River above Bankhead L\&D . . . . . . . (205) 339-3829

02462501 - Black Warrior River below Bankhead L\&D . . . . . . (205) 339-3829

02462952 - Black Warrior River below Holt L\&D .......... (205) 556-6357

02465000 - Black Warrior River above Oliver L\&D . . . . . . . (205) 752-6785

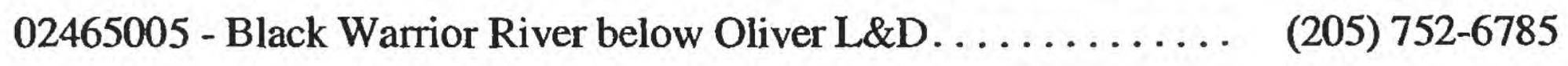

02467000 - Tombigbee River above Demopolis L\&D ......... (334) 289-9966

02467001 - Tombigbee River below Demopolis L\&D . . . . . . . . (334) 289-9966 
STREAMFLOW STATIONS WITH SATELLITE TELEMETRY (http://water.usgs.gov/):

CHATTAHOOCHEE RIVER BASIN

02342500 - Uchee Creek near Fort Mitchell

02342933 - South Fork Cowikee near Batesville

0234296910 - Chattahoochee River at Eufaula

02343801 - Chattahoochee River at Andrews (Pool)

02343802 - Chattahoochee River at Andrews (Tail)

CHOCTAWHATCHEE RIVER BASIN

02361000 - Choctawhatchee River near Newton

02361500 - Choctawhatchee River near Bellwood

02362240 - Little Double Bridges Creek near Enterprise

02363000 - Pea River near Ariton

02364000 - Pea River near Elba

BLACKWATER RIVER BASIN

02369800 - Blackwater River near Bradley

ESCAMBIA RIVER BASIN

02371500 - Conecuh River at Brantley

02372250 - Patsaliga Creek near Brantley

02372422 - Conecuh River near River Falls

02373000 - Sepulga River near McKenzie

02374250 - Conecuh River near Brewton

02374500 - Murder Creek near Evergreen

02374700 - Murder Creek at Brewton

02374745 - Burnt Corn Creek at Highway 41 near Brewton

02374950 - Big Escambia at Stanley Cross Roads

PERDIDO RIVER BASIN

02376115 - Eleven mile Creek near Pensacola, Florida

02376500 - Perdido River at Barrineau Park

02377570 - Styx River near Silverhill

FISH RIVER BASIN

02378300 - Magnolia River at U.S. Highway 98 near Foley

02378500 - Fish River near Silverhill

COOSA RIVER BASIN

02398037 - Chattooga River at Chattooga, Georgia

02398250 - Mills Creek at Dewey

02398300 - Chattooga River near Gaylesville

02398950 - West Fork Little River near Fort Payne

02399200 - Little River near Blue Pond

02399500 - Coosa River at Leesburg

02400100 - Terrapin Creek at Ellisville

02400496 - Coosa River at Steamplant near Gadsden

02400500 - Coosa River at Gadsden

02401000 - Big Wills Creek near Reece City 
STREAMFLOW STATIONS WITH SATELLITE TELEMETRY (continued):

02401390 - Big Canoe Creek at Ashville

02403395 - Choccolocco Creek at Oxford

02404400 - Choccolocco Creek near Lincoln

02405500 - Kelly Creek near Vincent

02406500 - Talladega Creek at Alpine

02407000 - Coosa River at Childersburg

02407526 - Coosa River at Steamplant near Wilsonville

02408540 - Hatchet Creek below Rockford

02411600 - Coosa River at Wetumpka

TALLAPOOSA RIVER BASIN

02411930 - Tallapoosa River below Tallapoosa, Georgia

02412000 - Tallapoosa River near Heflin

02413210 - Little Tallapoosa River below Bowdon

02413300 - Little Tallapoosa River near Newell

02414500 - Tallapoosa River at Wadley

02414715 - Tallapoosa river near New Site

02415000 - Hillabee Creek near Hackneyville

02418230 - Sougahatchee Creek near Loachapoka

02419000 - Uphapee Creek near Tuskegee

02419500 - Tallapoosa River at Milstead

02419890 - Tallapoosa River near Montgomery (Montgomery water plant)

UPPER ALABAMA RIVER BASIN

02419988 - Alabama River at Montgomery

02420000 - Alabama River at U.S. Highway 31 near Montgomery

02421000 - Catoma Creek near Montgomery

02421350 - Alabama River at Jones Bluff (Pool)

02421351 - Alabama River at Jones Bluff (Tail)

02422500 - Mulberry Creek at Jones

02423000 - Alabama River at Selma

CAHABA RIVER BASIN

02423130 - Cahaba River at Trussville

02423380 - Cahaba River near Mountain Brook

02423397 - Little Cahaba River below Leeds

02423398 - Little Cahaba River near Leeds

02423425 - Cahaba River near Cahaba Heights

02423496 - Cahaba River near Hoover

02423500 - Cahaba River near Acton

0242354750 - Cahaba Valley Creek at Pelham

02423555 - Cahaba River near Helena

02423586 - Shades Creek near Homewood

02423630 - Shades Creek near Greenwood

02424000 - Cahaba River at Centreville 
STREAMFLOW STATIONS WITH SATELLITE TELEMETRY (continued):

02424590 - Cahaba River near Suttle

02425000 - Cahaba River near Marion Junction

LOWER ALABAMA RIVER BASIN

02427250 - Pine Barren Creek near Snow Hill

02427505 - Alabama River Miller Ferry (Pool)

02427506 - Alabama River Miller Ferry (Tail)

02428400 - Alabama River near Claiborne (Pool)

02428401 - Alabama River near Claiborne (Tail)

02429540 - Alabama River at Choctaw Bluff near Carl

UPPER TOMBIGBEE RIVER BASIN

02438000 - Buttahatchee River below Hamilton

02442500 - Luxapallila Creek at Millport

02444160 - Tombigbee at Pickensville (Pool)

02444161 - Tombigbee at Pickensville (Tail)

02444490 - Bogue Chitto Creek near Memphis

02444500 - Tombigbee River near Cochrane

02446500 - Sipsey River near Elrod

02447025 - Tombigbee at Gainesville (Pool)

02447026 - Tombigbee at Gainesville (Tail)

02448500 - Noxubee River near Geiger

02448900 - Bodka Creek near Geiger

MULBERRY FORK BASIN

02449840 - Duck River near Berlin

02449882 - Blue Springs Creek near Blountsville

02450000 - Mulberry Fork near Garden City

02450180 - Mulberry Fork near Arkadelphia

02450250 - Sipsey Fork near Grayson

02450825 - Clear Creek near Poplar Springs

02453000 - Blackwater Creek near Manchester

02453500 - Mulberry Fork at Cordova

02454055 - Lost Creek above Parrish

\section{LOCUST FORK BASIN}

02455000 - Locust Fork near Cleveland

02455900 - Locust Fork at Warrior

02455980 - Turkey Creek near Pinson

02456000 - Turkey Creek at Morris

02456500 - Locust Fork at Sayre

02457000 - Fivemile Creek at Ketona

02457595 - Fivemile Creek at Republic

02457670 - Fivemile Creek near Graysville

02458148 - Village Creek at 86th Street at Roebuck

02458200 - Village Creek at Apalachee Street at Birmingham 


\section{STREAMFLOW STATIONS WITH SATELLITE TELEMETRY (continued):}

02458300 - Village Creek at 24th Street at Birmingham

02458450 - Village Creek at Avenue W near Ensley

02458502 - Village Creek near Pratt City

02458600 - Village Creek near Docena

BLACK WARRIOR RIVER BASIN

02461130 - Valley Creek at Birmingham

02461500 - Valley Creek near Bessemer

02461630 - Halls Creek at Bessemer

02461640 - Valley Creek at Bessemer

02462000 - Valley Creek near Oak Grove

02462500 - Black Warrior River at Bankhead (Pool)

02462501 - Black Warrior River at Bankhead (Tail)

02462951 - Black Warrior at Holt (Pool)

02462952 - Black Warrior at Holt (Tail)

02464000 - North River near Samantha

02464146 - Turkey Creek near Tuscaloosa

02464800 - Lake Tuscaloosa near Tuscaloosa

02465000 - Black Warrior River above Oliver Dam (Pool)

02465005 - Black Warrior River below Oliver Dam (Tail)

02465292 - Cribbs Mill Creek at Tuscaloosa

02465493 - Elliotts Creek at Moundville

02466030 - Black Warrior River near Eutaw (Pool)

02466031 - Black Warrior River near Eutaw (Tail)

LOWER TOMBIGBEE RIVER BASIN

02467000 - Tombigbee River at Demopolis (Pool)

02467001 - Tombigbee River at Demopolis (Tail)

02467500 - Sucarnoochee River at Livingston

02469525 - Tombigbee River near Nanafalia

02469761 - Tombigbee River at Coffeeville (Pool)

02469762 - Tombigbee River at Coffeeville (Tail)

02469800 - Satilpa Creek at Coffeeville

02470050 - Tombigbee River near Leroy

02470072 - Bassett Creek near Thomasville

MOBILE RIVER BASIN

02471001 - Chickasaw Creek near Kushla

02471013 - Threemile Creek at Ziegler Blvd.

0247101490 - Threemile Creek at Mobile

02471016 - Threemile Creek near Prichard

02471017 - Mobile River at State Docks at Mobile

02471078 - Fowl River near Laurendin 


\section{STREAMFLOW STATIONS WITH SATELLITE TELEMETRY (continued):}

PASCAGOULA RIVER BASIN

02479560 - Escatawpa River near Agricola, Mississippi

02479945 - Big Creek near Wilmer

02479980 - Crooked Creek near Fairview

02480004 - J.B. Converse Reservoir near Semmes

UPPER TENNESSEE RIVER BASIN

03573182 - Scarham Creek near McVille

03574500 - Paint Rock River at Woodville

0357526200 - Big Cove Creek near Huntsville

03575500 - Tennessee River at Whitesburg

0357568650 - Aldridge Creek at Toney Drive at Huntsville

0357568980 - Aldridge Creek at Sherwood Drive at Huntsville

03575700 - Aldridge Creek near Farley

03575830 - Indian Creek near Madison

0357586650 - Fagan Creek at Adams Street at Huntsville

0357587090 - West Fork Pinhook Blue Spring Road at Huntsville

0357587140 - East Fork Pinhook Creek at Winche Road at Huntsville

0357587400 - Pinhook Creek at Mastin Lake Road at Huntsville

0357587728 - Dallas Branch at Coleman Street at Huntsville

03575890 - Pinhook Creek at Clinton Avenue at Huntsville

0357591500 - Broglan Branch at Oakwood Avenue at Huntsville

03575933 - Broglan Branch at Clinton Avenue at Huntsville

03575950 - Huntsville Springs Branch at Johnson Road

03575980 - McDonald Creek at Patton Road at Huntsville

03576250 - Limestone Creek near Athens

03577150 - Tennessee River at Decatur

LOWER TENNESSEE RIVER BASIN

03586500 - Big Nance Creek at Courtland

03589500 - Tennessee River at Florence

03590680 - Tennessee River at Smithsonia 


\section{U.S. GEOLOGICAL SURVEY (WRD) OFFICES}

\section{Alabama:}

Tuscaloosa

Montgomery

Florida:

Tallahassee

Georgia:

Atlanta

Tifton

Albany

Mississippi:

Pearl

North Carolina-

Raleigh

South Carolina:

Columbia

Tennessee:

Nashville

Southeast Regional Office

Norcross
(205) 752-8104 ext 223

Field Office: Victor Stricklin

(334) 213-2332 ext 22

District Office: Leroy Pearman (Data Chief)

(334) 213-2332 ext 15

Surface Water (SW) Specialist: Scott Hedgecock

(334) 213-2332 ext 19

District Chief: Athena Clark

(850) 942-9500 ext 3028

District Office: Stewart Tomlinson

(770) 903-9100

Hydrologic Records: Brian McCallum 903-9127

Hydrologic Data Unit: John Kerestes 903-9134

Field Headquarters: George Bailey 903-9124

(912) 382-6353

Field Headquarters: Terry Nichols

(912) 430-8420

Field Headquarters: Mark Reynolds

(601) 933-2900

District Chief: Mickey Plunkett (601) 933-2940

Records Section: John Storm (601) 933-2951

(919) 571-4017

District Office: Jeanne Robbins (SW Specialist)

(919) 571-4073

Hydrologic Records Section: Ron Garrett

(803) 750-6118

District Office: Lamar Sanders (SW Specialist)

(803) 750-6112

Hydrologic Data Management Unit: Ted Cooney

(615) 837-4700

Data Chief: Paul Hampson

(615) 837-4732

George Law

(615) 837-4731

Rodney Knight (SW Specialist)

(770) 409-7717

Surface Water Specialist: Larry Bohman 


\section{NATIONAL OCEANIC AND ATMOSPHERIC ADMINISTRATION}

\section{Weather Service Forecast Offices}

Birmingham, Alabama: (205) 621-5645 ext 228

Mobile, Alabama: (251) 633-0921

$$
\text { Roger McNeil }
$$

Peachtree City, Georgia: (770) 486-0028

$$
\text { Keith Williams }
$$

Tallahassee, Florida: (850) 942-8837

$$
\text { Service Hydrologist }
$$

Joel Lanier

Recent rainfall and river stage data and current weather forecasts for Alabama and adjacent areas can be obtained from the appropriate (WSFO).

\section{Southeast River Forecast Centers}

Peachtree City, Georgia: (770) 486-0028

Slidell, Louisiana: (504) 641-4343

Hydrologist-in-Charge: Brad Gimmestad

Hydrologist-in-Charge: David Reed

The River Forecast Center uses real-time river stage and rainfall data, and rainfall-runoff models to forecast peak flood stages for major streams in the Southeast.

\section{Flood forecasts are available for the following sites:}

\section{Station name}

Choctawhatchee River nr Newton

Pea River at Elba

Coosa River at Leesburg

Coosa River at Gadsden

Coosa River at Childersburg

Coosa River at Wetumpka

Tallapoosa River at Wadley

Tallapoosa River at Milstead

Tallapoosa River near Montgomery

Alabama River at Montgomery

Catoma Creek near Montgomery

Alabama River at Robert F. Henry L\&D

Alabama River at Selma

$\begin{array}{ccc}\begin{array}{ccc}\text { Station } \\ \text { number }\end{array} & \begin{array}{c}\text { Flood } \\ \text { stage (ft) }\end{array} & \begin{array}{c}\text { Gaging } \\ \text { station }\end{array} \\ 02361000 & 19 & \text { Active } \\ 02364000 & 30 & \text { Active } \\ 02399500 & 564 & \text { Active } \\ 02400500 & 511 & \text { Active } \\ 02407000 & 402 & \text { Active } \\ 02411600 & 45 & \text { Active } \\ 02414500 & 13 & \text { Active } \\ 02419500 & 40 & \text { Active } \\ 02419890 & 25 & \text { Active } \\ 02419988 & 35 & \text { Active } \\ 02421000 & 20 & \text { Active } \\ 02421351 & 122 & \text { Active } \\ 02423000 & 45 & \text { Active }\end{array}$




\begin{tabular}{|c|c|c|c|}
\hline Station name & $\begin{array}{l}\text { Station } \\
\text { number }\end{array}$ & $\begin{array}{c}\text { Flood } \\
\text { stage (ft) }\end{array}$ & $\begin{array}{l}\text { Gaging } \\
\text { station }\end{array}$ \\
\hline Cahaba River near Cahaba Heights & 02423425 & 14 & Active \\
\hline Cahaba River at Centreville & 02424000 & 23 & Active \\
\hline Cahaba River near Suttle & 02424590 & 32 & Active \\
\hline Cahaba River near Marion Junction & 02425000 & 36 & Active \\
\hline Alabama River at Millers Ferry L\&D & 02427506 & 66 & Active \\
\hline Alabama River below Claiborne L\&D & 02428401 & 42 & Active \\
\hline Tombigbee River at Bevill L\&D & 02444160 & 122 & Active \\
\hline Tombigbee River at Heflin L\&D & 02447025 & 101 & Active \\
\hline Mulberry Fork at Cordova & 02453500 & 16 & Active \\
\hline Locust Fork at Sayre & 02456500 & 25 & Active \\
\hline Village Creek at Avenue W at Ensley & 02458450 & 10 & Active \\
\hline Black Warrior River at Bankhead L\&D & 02462500 & 189 & Active \\
\hline Black Warrior River at Holt L\&D & 02462951 & 140 & Active \\
\hline Black Warrior River at Oliver L\&D & 02465000 & 129 & Active \\
\hline Black Warrior River at Selden L\&D & 02466030 & 90 & Active \\
\hline Tombigbee River below Demopolis L\&D & 02467001 & 68 & Active \\
\hline Sucarnoochee River at Livingston & 02467500 & 18 & Active \\
\hline Tombigbee River below Coffeeville L\&D & 02469762 & 29 & Active \\
\hline Tombigbee River near Leroy & 02470050 & 24 & Active \\
\hline Paint Rock River near Woodville & 03574500 & 16 & Active \\
\hline Flint River near Chase & 03575000 & 16 & Inactive \\
\hline Tennessee River at Whitesburg & 03575500 & 18 & Active \\
\hline Tennessee River at Florence & 03589500 & 17 & Active \\
\hline
\end{tabular}




\section{ALABAMA POWER COMPANY OFFICE DIRECTORY}

Manager Environmental and Research: (205) 257-3220

Charles Stover

Coordinator Reservoir Operations: (205) 257-3207

Andy Sheppard

Load Dispatcher: (205) 257-3545 (Hours: 0800-1700)

Weekend Dispatcher: (205) 257-4010

\section{U.S. ARMY CORPS OF ENGINEERS OFFICE DIRECTORY}

Mobile District

$$
\begin{array}{ll}
\text { Hydraulic Data: } & \text { (334) 694-4016, Doug Otto } \\
\text { Water Management: } & \text { (334) 690-2737, General Operations } \\
& \text { (334) 690-2730, Memphis Vaughan } \\
& \text { (334) 690-3054, Glen Duval } \\
& \text { (334) 690-2733, Steve Lloyd } \\
\text { (334) 690-2735, James Hathorn } \\
\text { (334) 690-3386, Charles Yanny }
\end{array}
$$

\section{TENNESSEE VALLEY AUTHORITY OFFICE DIRECTORY}

Flood Information:

TVA OPERATOR: (865) 632-2101

Knoxville: (865) 632-6115, Roger Millstead

Knoxville: (865) 632-6851, Stephen C. Allen

Knoxville: (865) 632-6847, Steven Amick

\section{Data Management Section:}

Knoxville: (865) 632-2859, Edward Thornton

Knoxville: (865) 632-4222, L. Wayne Hamberger

\section{Reservoir Operations:}

Knoxville: (865) 632-7063, Lead Engineer

Field Offices:

Knoxville: (865) 632-6065 Janice Pinkston

Knoxville: (865) 632-1901, Chuck Bach (Supervisor)

Knoxville: (865) 632-4483, Steve McLemore (Supervisor)

Knoxville: (865) 632-2420, Brent Alexander

Muscle Shoals: (256) 368-2485. Robert Atwell 
City

Birmingham:

Decatur:

Dothan:

Evergreen:

Eufaula:

Huntsville:

Jacksonville:

Mobile:

Montgomery:

Opelika:

Selma:

Sheffield:

Tuscaloosa:
Telephone number

(205) $322-4601$

(256) 353-0631

(334) $983-4587$

(251) $578-1315$

(334) 687-2054

(256) $533-4202$

(256) $435-3521$

(251) $660-2300$

(334) $242-4128$

(334) $745-4651$

(334) $874-8234$

(256) $383-9212$

(205) $553-5531$ 
1 st Division - Guntersville:

Telephone number

[Cullman, DeKalb, Jackson, Madison, (256) $582-2254$

Marshall, Morgan]

District 1 Engineer - Tanner:

(256) 353-8862

District 2 Engineer - Huntsville:

(256) 837-0111

District 3 Engineer - Dutton:

(256) 228-6028

District 4 Engineer - Joppa:

(256) $586-4178$

2nd Division - Tuscumbia:

District 1 Engineer - Tuscumbia:

(256) 389-1401

(256) 389-1441

District 2 Engineer - Moulton:

District 3 Engineer - Hamilton:

(256) $974-0648$

(205) 921-2117

3rd Division - Birmingham:

(205) 581-5603

District 1 Engineer - Birmingham: (205) $581-5702$

District 2 Engineer - Oneonta:

District 3 Engineer - Gadsden:

(205) $274-2112$

(256) $442-4436$

District 4 Engineer - Jasper:

(205) 221-9128

District 5 Engineer - Calera:

(205) 668-0173

4th Division - Alexander Citv:

(256) 234-8401

[Calhoun, Chambers, Clay, Cleburne,

Coosa, Lee, Randolph, Russell, Tallapoosa, Talladega]

District 1 Engineer - Alexander City:

(256) 234-8481

District 2 Engineer - Anniston:

(256) $820-3131$

District 3 Engineer - Opelika:

(334) $887-3341$

District 4 Engineer - Delta:

(256) $253-2158$

District 5 Engineer - Talladega:

(256) $362-1240$

District 6 Engineer - Seale:

(334) $855-4735$

5th Division - Tuscaloosa:

(205) 553-7030

[Bibb, Chilton, Fayette, Green, Hale, Lamar, Pickens, Perry, Tuscaloosa]

District 1 Engineer - Fayette:

(205) $932-8939$

District 2 Engineer - Tuscaloosa:

(205) $554-3288$

District 3 Engineer - Carrollton:

(205) $367-8746$

District 4 Engineer - Maplesville:

(334) $366-2954$

District 5 Engineer - Greensboro:

(334) 624-8851 
Telephone number

6th Division - Montgomery:

[Autauga, Bullock, Butler, Dallas, Elmore, Lowndes, Macon, Montgomery]

District 1 Engineer - Elmore:

(334) $567-4379$

District 2 Engineer - Union Springs:

(334) $738-2150$

District 3 Engineer - Montgomery:

(334) $242-6572$

District 4 Engineer - Greenville:

(334) 382-6614

District 5 Engineer - Selma:

(334) $875-4455$

7th Division - Troy:

(334) $670-2420$

[Barbour, Coffee, Covington, Crenshaw, Dale, Geneva, Henry, Houston, Pike]

District 1 Engineer - Dothan:

(334) 794-4958

District 2 Engineer - Enterprise:

(334) $347-8166$

District 3 Engineer - Andalusia:

(334) 222-5555

District 4 Engineer - Ozark:

(334) $774-4542$

District 5 Engineer - Troy:

(334) $670-2475$

District 6 Engineer - Eufaula:

(334) 687-3161

8th Division - Grove Hill:

(334) $275-4103$

[Choctaw, Clarke, Marengo, Monroe,

Sumter, Washington, Wilcox]

District 1 Engineer - Livingston:

(205) 652-7964

District 2 Engineer - Thomaston:

(334) $627-3458$

District 3 Engineer - Camden:

(334) $682-4718$

District 4 Engineer - Grove Hill:

(334) $275-3675$

9th Division - Mobile:

(251) $470-8204$

[Baldwin, Conecuh, Escambia, Mobile]

District 1 Engineer - Mobile:

(251) $470-8209$

District 2 Engineer - Bay Minette:

(251) $937-2086$

District 3 Engineer - Evergreen:

(251) $578-2434$ 


\section{PROJECT ALERT (WRD Memorandum 90.22)}

The purpose of Project Alert is to notify U.S. Geological Survey and Department of the Interior officials of significant or unusual hydrologic events so that they may disseminate information about the event to the news media and arrange for emergency operations, if necessary.

Descriptions of significant or unusual water events of interest should include the following:

- Floods and the imminent threat of floods--Information should include all of those data shown on the attached form, used for the National Water Conditions. If all information is not readily available, prompt reporting is more important: additional information can be relayed later. This report format does fit electronic mail -- California, Nevada, Virginia, West Virginia, and other States used it to submit data for floods which affected many sites in those States in the last several years (Note that when a peak discharge exceeds that for the 100 -year flood, the ratio of the peak discharge to that of the 100-year flood should be furnished). Flood forecasts, rainfall data, and damage estimates are helpful for background. Floods with recurrence intervals of less than 10 years are not to be reported unless lives are lost or damages are widespread or sizable (in the hundreds or thousands of dollars). Information desired by the Public Affairs Office for record-high or near-record-high streamflows or where damages are newsworthy is shown on page A4 of this attachment.

- Lake and reservoir levels--Extremely high or low water levels and associated effects on shorelines, water quality, or water supplies.

- Droughts--Location and extent of areas affected by persistent low flows, low reservoir levels, declining ground-water levels, and dry soil moisture conditions that may restrict water use and affect crops and wildlife. Provisional data should include date, stream name and location, gaging station number, discharge, drainage area, recurrence interval, and comparative ranking with previous low flows. Data on rainfall, soil moisture conditions, and damage estimates are helpful for background. Descriptions of emergency actions taken by local agencies to conserve water, reduce demand, or obtain emergency supplies also will help put the event in perspective.

- Toxic and radiological spills--Reports of significant toxic and radiological spills in waterways, lakes, reservoirs, and on the ground should include date, water body name, location and nature of spill, amount of spill, water supplies endangered, and cleanup actions being taken. Effects might include fish kills, temporary closing of watertreatment plants downstream from the spills, closing of water bodies to swimming or fishing, or closing of wells.

- Ground-water levels--Location and extent of unusually high or low ground-water levels and their effects.

- Ground-water contamination--Reports of newly discovered ground-water contamination should include date of discovery, well location, contaminant, extent of contamination, and actions being taken such as the closing of wells or well fields. Population affected by the closure of a water-supply well would be useful for background interest. Contaminants include, but are not limited to, salt, radioactive materials, petroleum products, organics, trace metals, nitrates, and bacteria. 
Other water-related events of unusual severity that should be reported include, but are not limited to, ice jams, mudflows, and subsidence. If an event is determined to be newsworthy. then speed in reporting the event is essential.

To facilitate the flow of information, the following actions should be taken:

(1) As soon as preliminary data are available, they should be entered on the Project Alert Web Page: water.usgs.gov/project_alert and follow the instructions on that page, or

(2) fax information to (703) 648-5295. Use forms on pages B-35 and B-36 for types of data needed to report to Headquarters, or

(3) email information to: project_alert@usgs.gov 


\section{FLOOD NEWS REPORT FORM FOR USE BY USGS PUBLIC AFFAIRS OFFICE}

1. WRD DISTRICT/STATE

DATE

2. NAME OF PREPARER

TELEPHONE NUMBER

3. NAME OF STREAM

4. LOCATION OF GAGE

5. PEAK STREAMFLOW IN CFS

RECURRENCE INTERVAL (YEARS, OR RATIO TO 100-YEAR FLOOD IF > 100 YEARS)

DATE OF PEAK

6. IS THIS A NEW PEAK OF RECORD?

NO

YES (SKIP 7)

7. LAST TIME THIS FLOW WAS EXCEEDED:

DATE

(IF CURRENT PEAK IS NOT PEAK OF RECORD)

FLOW IN CFS

8. AT THE TIME OF MEASUREMENT/READING, FLOW WAS:

AT ITS PEAK

(CHECK ONE IF DISCHARGE MEASUREMENT OR

INCREASING

NON-PEAK FLOW IS BEING REPORTED)

DECREASING

9. PREVIOUS RECORD HIGH:

FLOW IN CFS__ DATE

STAGE IN FEET

DATE

(IF NOT CONCURRENT

WITH PEAK FLOW)

10. OTHER INFORMATION:

NOTE: When reporting streamflow for a flood, give at least the highest flow/stage which has occurred so far. This information is always important but is of particular interest if the previous record high has been exceeded, even if flow has not yet peaked. Aiso, data indicating how flow is changing, both before and after the peak occurs, is important when reporting major floods on large rivers. 
AL-1

\section{FLOOD DATA INFORMATION FORM}

\begin{tabular}{|c|c|}
\hline Date & Time \\
\hline Stage_ & dh/dt \\
\hline Peak stage_ & _Time_ \\
\hline
\end{tabular}

Discharge Measurements:

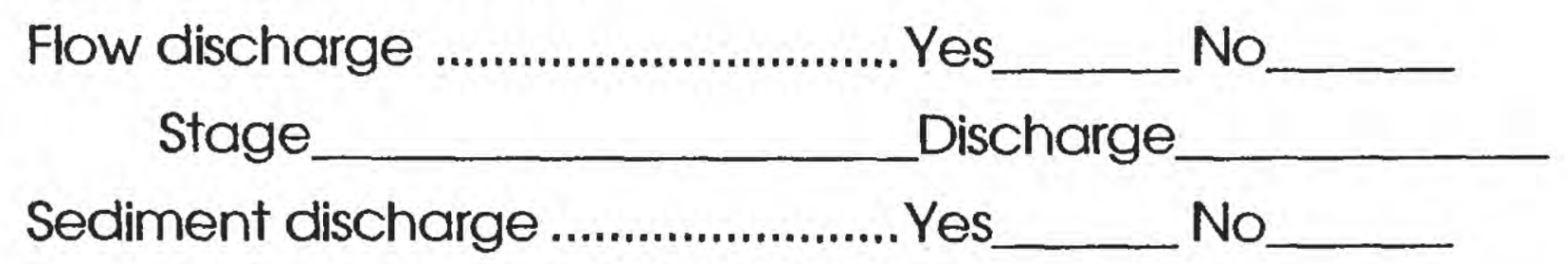

Weather and road conditions

Additional remark 


\section{ALABAMA DISTRICT FLOOD PLAN - Appendix 3}

STATION PRIORITY LIST

Active Continuous Record Stations

[*, special bridge/traffic considerations; ${ }^{* *}$ bridge/flag indirect measurement; $\mathrm{H}$, high; $\mathrm{M}$, moderate; $\mathrm{L}$ low]

\begin{tabular}{|c|c|c|c|c|c|}
\hline Station number and name & $\begin{array}{c}\text { Drainage } \\
\text { area } \\
\text { (square } \\
\text { mile) }\end{array}$ & $\begin{array}{c}\text { Observed } \\
\text { maximum } \\
\text { stage } \\
\text { (feet) }\end{array}$ & $\begin{array}{l}\text { Maximum } \\
\text { stage } \\
\text { measure- } \\
\text { ment }\end{array}$ & $\begin{array}{l}\text { Measurement } \\
\text { above stage }\end{array}$ & Priority \\
\hline 02342500 Uchee Creek near Fort Mitchell & 322 & (I) 26.45 & (I) 26.45 & 20.00 & $\mathbf{L}$ \\
\hline 02342933 South Fork Cowikee Creek near Batesville & 112 & 43.40 & 36.82 & 15.00 & M \\
\hline 02361000 Choctawhatchee River near Newton & 686 & 40.30 & 40.27 & 25.00 & $\mathbf{H}$ \\
\hline 02361500 Choctawhatchee River near Bellwood & 1,280 & 15.70 & (I) 15.70 & 17.00 & $\mathbf{H}$ \\
\hline 02362240 Little Double Bridges Creek nr Enterprise & 21.4 & 16.45 & (I) 13.40 & 12.00 & $\mathbf{H}$ \\
\hline 02363000 Pea River near Ariton & 498 & 24.87 & 24.36 & 17.00 & L \\
\hline 02364000 Pea River at Elba & 959 & 43.5 & 37.90 & 40.00 & M \\
\hline 02369800 Blackwater River near Bradley & 87.7 & 25.35 & 23.00 & 18.00 & $\mathbf{M}$ \\
\hline 02371500 Conecuh River at Brantley & 500 & 24.51 & 24.51 & 22.00 & $\mathbf{L}$ \\
\hline 02372250 Patsaliga Creek near Brantley & 442 & 25.67 & 24.40 & 25.00 & M \\
\hline 02372422 Conecuh River near River Falls & 1,273 & 52.5 & 48.4 & 45.00 & $\mathrm{H}$ \\
\hline 02373000 Sepulga River near McKenzie & 470 & 33.0 & 25.54 & 25.00 & $\mathbf{L}$ \\
\hline 02374250 Conecuh River at Highway 41, Brewton & 2,661 & 46.6 & 30.16 & 30.00 & $\mathbf{H}$ \\
\hline 02374500 Murder Creek near Evergreen & 1,76 & 26.6 & 15.18 & 15.00 & $\mathbf{L}$ \\
\hline 02374700 Murder Creek at Brewton & 435 & 37.0 & 25.81 & 26.00 & M \\
\hline 02374745 Burnt Corn Creek near Brewton & 182 & 22.15 & 21.91 & 22.00 & M \\
\hline 02374950 Big Escambia Creek nr Stanley Crossroads & 143 & 16.63 & 13.63 & 14.00 & $\mathrm{H}$ \\
\hline 02375500 Escambia River near Century, Florida & 3,817 & 37.8 & -- & \multicolumn{2}{|c|}{ Florida Station } \\
\hline 02376500 Perdido River at Barrineau Park & 2,394 & 26.30 & (D) 26.18 & 26.00 & M \\
\hline 02377570 Styx River near Elsanor & 192 & 28.60 & 26.65 & 27.00 & $\mathbf{M}$ \\
\hline 02378300 Magnolia River near Foley & 16.6 & 8.36 & 7.62 & 8.00 & $\mathrm{H}$ \\
\hline 02378500 Fish River near Silverhill & 55.3 & 22.78 & 22.26 & 22.00 & $\mathbf{M}$ \\
\hline 02348037 Chattooga River nr Chatoogaville, Georgia & 281 & 17.49 & 9.10 & 5.00 & $\mathbf{H}$ \\
\hline 02398300 Chattooga River above Gaylesville & 366 & 24.25 & 21.98 & 20.00 & $\mathbf{L}$ \\
\hline 02398950 West Fork Little River near Fort Payne & 42.8 & 11.18 & 8.55 & 9.00 & $M(*)$ \\
\hline 02399200 Little River near Blue Pond & 199 & 16.98 & (I) 16.98 & 10.00 & $\mathbf{M}$ \\
\hline
\end{tabular}


Active Continuous Record Stations

[*, special bridge/traffic considerations; ** bridge/flag indirect measurement; $\mathrm{H}$, high; $\mathrm{M}$, moderate; $\mathrm{L}$ low]

\begin{tabular}{|c|c|c|c|c|c|}
\hline Station number and name & $\begin{array}{c}\text { Drainage } \\
\text { area } \\
\text { (square } \\
\text { mile) }\end{array}$ & $\begin{array}{c}\text { Observed } \\
\text { maximum } \\
\text { stage } \\
\text { (feet) }\end{array}$ & $\begin{array}{c}\text { Maximum } \\
\text { stage } \\
\text { measure- } \\
\text { ment }\end{array}$ & $\begin{array}{l}\text { Measurement } \\
\text { above stage }\end{array}$ & Priority \\
\hline 02400100 Terrapin Creek at Ellisville & 252 & 19.82 & 15.52 & 16.00 & $\mathbf{H}$ \\
\hline 02401000 Big Wills Creek near Reece City & 182 & 16.3 & 14.37 & 14.00 & M \\
\hline 02401390 Big Canoe Creek at Ashville & 141 & 18.75 & 18.75 & 17.00 & $\mathbf{L}$ \\
\hline 02403395 Choccolocco Creek at Oxford & 222 & 11.85 & 11.53 & 11.00 & $\mathbf{H}$ \\
\hline 02404400 Choccolocco Creek near Lincoln & 481 & 42.4 & 39.84 & 32.00 & $\mathbf{L}$ \\
\hline 02405500 Kelly Creek near Vincent & 193 & 27.39 & (I) 27.08 & 25.00 & $\mathbf{L}$ \\
\hline 02406500 Talladega Creek at Alpine & 150 & 16.60 & (I) 16.60 & 14.00 & M \\
\hline 02408540 Hatchet Creek below Rockford & 263 & 27.90 & 24.14 & 7.00 & $\mathbf{L}$ \\
\hline 02411000 Coosa River near Wetumpka & 10,102 & 47.67 & - & \multicolumn{2}{|c|}{-- as needed } \\
\hline 02411930 Tallapoosa River below Tallapoosa & 272 & 12.87 & 9.40 & 10.00 & $\mathbf{H}$ \\
\hline 02412000 Tallapoosa River near Heflin & 448 & 31.34 & 31.14 & 20.00 & M \\
\hline 02413300 Little Tallapoosa River below Bowden & 245 & 11.74 & 11.54 & 11.00 & $\mathbf{H}$ \\
\hline 02413300 Little Tallapoosa River near Newell & 406 & 19.30 & 18.10 & 10.00 & $\mathbf{H}$ \\
\hline 02414500 Tallapoosa River at Wadley & 1,675 & 26.72 & 26.37 & 20.00 & $\mathbf{M}$ \\
\hline 02414715 Tallapoosa River near New Site & 2,058 & 19.15 & 13.50 & 14.00 & $\mathbf{H}$ \\
\hline 02415000 Hillabee Creek near Hackneyville & 190 & 28.10 & 23.43 & 10.00 & L \\
\hline 02418230 Sougahatchee Creek near Loachapoka & 71.3 & 7.88 & 7.44 & 7.50 & $\mathbf{H}$ \\
\hline 02418500 Tallapoosa River below Tallassee & 3,328 & 51.35 & - & \multicolumn{2}{|c|}{ - as needed } \\
\hline 02419000 Uphapee Creek near Tuskegee & 333 & 28.17 & 26.12 & 24.00 & $\mathbf{L}$ \\
\hline 02419890 Tallapoosa River near Montgomery & 4,646 & 41.9 & 35.29 & 36.00 & $\mathbf{L}$ \\
\hline 02421000 Catoma Creek near Montgomery & 290 & 29.78 & 28.82 & 29.00 & $\mathbf{L}$ \\
\hline 02422500 Mulberry Creek at Jones & 203 & 33.6 & 29.34 & 21.00 & $\mathbf{H}$ \\
\hline 02423130 Cahaba River at Trussville & 19.7 & 10.46 & 9.72 & 7.00 & $\mathbf{L}$ \\
\hline 02423380 Cahaba River near Mountain Brook & 140 & 16.19 & 14.57 & 12.00 & $\mathbf{L}$ \\
\hline 02423397 Little Cahaba River below Leeds & 17.0 & 12.92 & I & 6.00 & $(* *)$ \\
\hline 02423398 Little Cahaba River near Leeds & 19.4 & 12.11 & 8.95 & 8.00 & $\mathbf{M}$ \\
\hline 02423425 Cahaba River near Cahaba Heights & 201 & 28.86 & 28.57 & 20.00 & $M(*)$ \\
\hline 02423496 Cahaba River near Hoover & 226 & 34.38 & 13.24 & 15.00 & $\mathrm{M}(*)$ \\
\hline
\end{tabular}


Active Continuous Record Stations

[*, special bridge/traffic considerations; ** bridge/flag indirect measurement; $\mathrm{H}$, high; $\mathrm{M}$, moderate; L low]

\begin{tabular}{|c|c|c|c|c|c|}
\hline Station number and name & $\begin{array}{l}\text { Drainage } \\
\text { area } \\
\text { (square } \\
\text { mile) }\end{array}$ & $\begin{array}{c}\text { Observed } \\
\text { maximum } \\
\text { stage } \\
\text { (feet) }\end{array}$ & $\begin{array}{c}\text { Maximum } \\
\text { stage } \\
\text { measure- } \\
\text { ment }\end{array}$ & $\begin{array}{l}\text { Measurement } \\
\text { above stage }\end{array}$ & Priority \\
\hline 02423500 Cahaba River near Acton & 230 & 44.25 & 39.83 & 35.00 & L \\
\hline 0242354750 Cahaba Valley Creek at Pelham & 25.6 & 10.89 & 9.93 & 8.00 & $\mathbf{M}$ \\
\hline 02423555 Cahaba River near Helena & 335 & 34.85 & 3.55 & 20.00 & $M(*)$ \\
\hline 02423630 Shades Creek near Greenwood & 72.3 & 15.19 & 13.87 & 13.00 & $\mathbf{M}$ \\
\hline 02424000 Cahaba River at Centreville & 1,027 & 36.63 & 34.96 & 25.00 & $\mathbf{L}$ \\
\hline 02424590 Cahaba River nesr Suttle & 1,480 & 44.0 & 40.95 & 41.00 & $\mathbf{M}$ \\
\hline 02425000 Cahaba River near Marion Junction & 1,766 & 43.80 & 41.53 & 42.00 & L \\
\hline 02427250 Pine Barren Creek near Snow Hill & 261 & 25.70 & 25.45 & 25.50 & $\mathrm{~L}$ \\
\hline 02428400 Alabama River at Claiborne L\&D & 21,473 & 57.59 & - & \multicolumn{2}{|c|}{ - as needed } \\
\hline 02438000 Buttahatchee River below Hamilton & 277 & 35.49 & 35.36 & 15.00 & M \\
\hline 02442500 Luxapallila Creek at Millport & 247 & 14.07 & 13.65 & 13.00 & $\mathrm{~L}$ \\
\hline 02444160 Tombigbee River at Bevil L\&D & 5,750 & 44.33 & -- & \multicolumn{2}{|c|}{ - as needed } \\
\hline 02444490 Bogue Chottp Creek near Memphis & 52.6 & 16.29 & 13.15 & 14.00 & $\mathrm{H}$ \\
\hline 02446500 Sipsey River near Elrod & 528 & 18.83 & 18.63 & 15.00 & $\mathbf{L}$ \\
\hline 02447025 Tombigbee River at Heflin L\&D & 7,230 & 120.74 & -- & -- & \\
\hline 02448500 Noxubee River near Geiger & 1,097 & 48.58 & 47.54 & 35.00 & $\mathrm{~L}(*)$ \\
\hline 02448900 Bodka Creek near Geiger & 158 & 24.20 & 21.87 & 20.00 & $M(*)$ \\
\hline 02449882 Blue Springs Creek near Blountsville & 13.0 & 11.37 & 4.97 & (I) 10.00 & $M(* *)$ \\
\hline 02450000 Mulberry Fork near Garden City & 365 & 25.04 & 21.65 & 15.00 & M \\
\hline 02450180 Mulberry Fork near Arkadelphia & 487 & 42.90 & 42.58 & 15.00 & $\mathbf{L}$ \\
\hline 02450250 Sipsey Fork near Grayson & 92.1 & 44.27 & 44.20 & 20.00 & $\mathbf{L}$ \\
\hline 02450825 Clear Creek near Popular Spring & 101 & 17.74 & 13.54 & 10.00 & M \\
\hline 02453000 Blackwater Creek near Manchester & 181 & 13.10 & 9.65 & 8.00 & $\mathbf{L}$ \\
\hline 02454055 Lost Creek above Parrish & 143 & 29.48 & 20.10 & 20.00 & $\mathbf{M}$ \\
\hline 02455000 Locust Fork near Cleveland & 303 & 19.20 & 12.24 & 15.00 & $\mathbf{M}$ \\
\hline 02455900 Locust Fork at Warrior & 707 & 29.61 & 22.98 & 25.00 & $\mathrm{H}$ \\
\hline 02455980 Turkey Creek near Pinson & 27.4 & 16.17 & (I) 16.17 & (I) 10.00 & $M(* *)$ \\
\hline 02456000 Turkey Creek at Morris & 80.9 & 23.12 & 22.11 & 10.00 & $\mathrm{H}$ \\
\hline
\end{tabular}


Active Continuous Record Stations

[*, special bridge/traffic considerations; ** bridge/flag indirect measurement; $\mathrm{H}$, high; $\mathrm{M}$, moderate; $\mathrm{L}$ low]

\begin{tabular}{|c|c|c|c|c|c|}
\hline Station number and name & $\begin{array}{c}\text { Drainage } \\
\text { area } \\
\text { (square } \\
\text { mile) }\end{array}$ & $\begin{array}{c}\text { Observed } \\
\text { maximum } \\
\text { stage } \\
\text { (feet) }\end{array}$ & $\begin{array}{l}\text { Maximum } \\
\text { stage } \\
\text { measure- } \\
\text { ment }\end{array}$ & $\begin{array}{l}\text { Measurement } \\
\text { above stage }\end{array}$ & Priority \\
\hline 02456500 Locust Fork at Sayre & 885 & 48.60 & 48.44 & (I) 20.00 & $\mathbf{L}$ \\
\hline 02457000 Fivemile Creek at Ketona & 23.9 & 17.28 & (I) 5.15 & 10.00 & M \\
\hline 02457595 Fivemile Creek near Republic & 51.9 & 18.35 & (I) 18.35 & 12.00 & $\mathbf{L}$ \\
\hline 02457670 Fivemile Creek near Graysville & 91.7 & 18.24 & (I) 16.45 & 10.00 & $M(* *)$ \\
\hline 02458148 Village Creek at Roebuck & 4.10 & 10.98 & (I) 10.98 & 5.00 & M \\
\hline 02458200 Village Creek at Birmingham & 15.6 & 18.78 & 10.55 & 10.00 & $\mathbf{M}$ \\
\hline 02458300 Village Creek at Birmingham & 26.0 & 13.23 & 11.65 & 12.00 & $\mathbf{M}$ \\
\hline 02458450 Village Creek at Ensley & 33.5 & 13.70 & 9.18 & 10.00 & $\mathrm{H}$ \\
\hline 02458502 Village Creek near Pratt City & 36.7 & 17.67 & 15.90 & (I) 15.00 & $M(* *)$ \\
\hline 02458600 Village Creek near Docena & 52.2 & 11.93 & 11.92 & 8.00 & $\mathrm{H}$ \\
\hline 02461130 Valley Creek at Birmingham & 7.00 & 12.06 & (I) 12.06 & 7.00 & $\mathbf{H}$ \\
\hline 02461500 Valley Creek near Bessemer & 52.5 & 18.6 & 10.69 & 10.50 & M \\
\hline 02461640 Halls Creek at Bessemer & 7.30 & 13.16 & 10.17 & 8.00 & $\mathbf{M}$ \\
\hline 02461640 Valley Creek below Bessemer & 61.4 & 13.24 & 6.51 & 7.00 & $\mathrm{H}$ \\
\hline 02462000 Valley Creek near Oak Grove & 148 & 33.98 & 28.86 & 25.00 & $M(*)$ \\
\hline O2462500 Black Warrior River at Bankhead L\&D & 3,981 & 255.60 & -- & \multicolumn{2}{|c|}{ - as needed } \\
\hline 02462951 Black Warrior River at Holt L\&D & 4,219 & 190.19 & - & \multicolumn{2}{|c|}{-- as needed } \\
\hline 02464000 North River near Samantha & 223 & 35.08 & 34.16 & 25.00 & M \\
\hline 02464146 Turkey Creek near Tuscaloosa & 6.16 & 11.98 & 4.35 & 5.00 & $\mathbf{H}$ \\
\hline 02464360 Binion Creek near Samantha & 57.2 & 15.19 & 11.22 & 12.00 & $\mathbf{H}$ \\
\hline 02465000 Black Warrior River at Oliver L\&D & 4,820 & 155.05 & -- & \multicolumn{2}{|c|}{-- as needed } \\
\hline 02465493 Elliotts Creek at Moundville & 32.3 & 8.80 & 8.21 & 8.00 & H \\
\hline 02466030 Black Warrior River at Selden L\&D & 5,810 & 108.87 & -- & \multicolumn{2}{|c|}{-- as needed } \\
\hline 02467000 Tombigbee River at Demopolis L\&D & 15,385 & 93.03 & - & \multicolumn{2}{|c|}{-- as needed } \\
\hline 02467500 Sucarnoochee River at Livingston & 607 & 33.47 & 32.88 & 20.00 & $\mathbf{L}$ \\
\hline 02469761 Tombigbee River at Coffeeville L\&D & 18,417 & 53.4 & -- & \multicolumn{2}{|c|}{-- as needed } \\
\hline 02469800 Satilpa Creek near Coffeeville & 164 & 18.37 & 16.04 & 16.00 & $\mathrm{H}$ \\
\hline 02470072 Bassett Creek near Thomasville & 10.5 & 10.33 & 9.79 & 10.00 & $\mathrm{H}$ \\
\hline
\end{tabular}




\section{Active Continuous Record Stations}

[*, special bridge/traffic considerations; ** bridge/flag indirect measurement; $\mathrm{H}$, high; $\mathrm{M}$, moderate; L low]

\begin{tabular}{|c|c|c|c|c|c|}
\hline Station number and name & $\begin{array}{l}\text { Drainage } \\
\text { area } \\
\text { (square } \\
\text { mile) }\end{array}$ & $\begin{array}{c}\text { Observed } \\
\text { maximum } \\
\text { stage } \\
\text { (feet) }\end{array}$ & $\begin{array}{l}\text { Maximum } \\
\text { stage } \\
\text { measure- } \\
\text { ment }\end{array}$ & $\begin{array}{l}\text { Measurement } \\
\text { above stage }\end{array}$ & Priority \\
\hline 02471001 Chickasaw Creek near Kushla & 125 & 25.40 & 22.14 & 23.00 & M \\
\hline 02471078 Fowl River near Laurendine & 16.5 & 12.56 & 10.13 & 11.00 & $\mathrm{H}$ \\
\hline 02479560 Escatawpa River nr Agricola, Mississippi & 562 & 22.81 & 22.72 & 22.80 & $\mathbf{L}$ \\
\hline 02479945 Big Creek near Wilmer & 31.5 & 14.21 & 12.61 & 13.00 & M \\
\hline 02479980 Crooked Creek near Fairview & 8.08 & 8.59 & 3.14 & (l) 4.00 & $M(* *)$ \\
\hline 02480002 Hamilton Creek near Semmes & 8.22 & 8.70 & 6.98 & 7.00 & $H(*)$ \\
\hline 03573182 Scarham Creek near McVille & 50.0 & 12.48 & 5.16 & 6.00 & $\mathbf{H}$ \\
\hline 03574500 Paint Rock River near Woodville & 320 & 24.40 & 22.46 & 20.00 & $\mathbf{L}$ \\
\hline 0357526200 Big Cove Creek near Huntsville & 4.89 & 12.20 & 12.18 & (I) & $\mathbf{L}$ \\
\hline 0357526200 Aldridge Creek at Toney Drive & 1.41 & 9.40 & 3.19 & (I) & $\mathbf{L}$ \\
\hline 0357568980 Aldridge Creek at Sherwood Drive & 6.97 & 14.55 & 4.27 & (I) & $\mathbf{L}$ \\
\hline 03575700 Aldridge Creek near Farley & 13.0 & 13.78 & 7.98 & (I) & $\mathbf{L}$ \\
\hline 03575830 Indian Creek near Madison & 49.0 & 12.70 & 11.49 & 8.00 & M \\
\hline 0357586650 Fagan Creek at Huntsville & 3.44 & 5.50 & -- & (I) & $\mathbf{L}$ \\
\hline 0357587090 West Fork Pinhook Creek at Huntsville & 2.28 & 9.18 & -- & (I) & $\mathbf{L}$ \\
\hline 0357587140 East Fork Pinhook Creek at Huntsville & 2.52 & 8.19 & -- & (I) & $\mathbf{L}$ \\
\hline 0357587400 Pinhook Creek at Mastin Lake Road & 8.50 & 8.89 & - & (I) & $\mathbf{L}$ \\
\hline 0357587728 Dallas Branch at Huntsville & 2.99 & 5.20 & 1.70 & (I) & L \\
\hline 03575890 Pinhook Creek at Huntsville & 22.6 & 16.48 & (I) 16.50 & (I) & $\mathbf{L}$ \\
\hline 0257591500 Broglan Branch at Huntsville & 1.47 & 12.90 & -- & (I) & $\mathbf{L}$ \\
\hline 03575933 Broglan Branch near Huntsville & 8.93 & 10.15 & - & (I) & $\mathbf{L}$ \\
\hline 03575950 Huntsville Spring Branch near Huntsville & 41.8 & 20.14 & 11.24 & (I) & $\mathbf{L}$ \\
\hline 03575980 McDonald Creek near Huntsville & 9.64 & 14.21 & -- & (I) & $\mathbf{L}$ \\
\hline 03576250 Limestone Creek near Athens & 119 & 17.48 & 14.03 & 8.00 & $\mathrm{H}(*)$ \\
\hline 03586500 Big Nance Creek at Courtland & 166 & 24.97 & 24.50 & 16.00 & M \\
\hline
\end{tabular}

Note: Huntsville sites shown above are all primarily flood hydrograph sites with recording gages and crest-stage gages utilized in making indirect measurements on several peaks during most year. 


\section{ALABAMA DISTRICT FLOOD PLAN - Appendix 4}

\section{SPECIAL PROBLEMS IN CONVENTIONAL CURRENT-METER MEASUREMENTS:}

\section{MEASUREMENT OF DEEP, SWIFT STREAMS}

Measurement of deep swift streams presents no serious problems when a sounding weight of sufficient size is available and there is not an excessive amount of drift and/or ice flowing in the stream. However, there are times when it is necessary to alter our normal stream gaging procedures when gaging deep swift streams. The six most common circumstances are listed below:

1. Able to sound but weight and meter drift downstream.

2. Cannot sound; standard cross section available.

3. Cannot sound; standard cross section not available.

4. Cannot put meter in water.

5. Measurements during rapidly changing stage.

6. Series of measurements needed during a peak of short duration.

The procedures outlined for items 2, 3, and 4 above assume that there is a stable cross section. At stations with unstable channels it is necessary to decide on a procedure based on the situation at each station.

1. The first item, when measuring where soundings can be obtained but the weight and meter drift downstream, is adequately covered on pages 159-170 of Volume I of WSP 2175. The use of tags on the sounding line and stay lines is also discussed.

2. The procedure to follow when measuring where a standard cross section is available, but where it is impossible to make soundings, is:

A. Determine the depths from the standard cross section.
B. Measure the velocity at the 0.2 depth.

C. Determine coefficients to adjust the $\mathbf{0 . 2}$ depth velocities to the mean velocity in the vertical on the basis of previous measurements made by the 0.2 and 0.8 depth method.

D. Compute the measurement in the normal manner using the depths from the standard cross section and the velocities as adjusted in step C.

3. The procedure to follow when measuring where it is impossible to obtain soundings and a standard cross section is not available is:

A. Reference the water-surface elevation before and after the measurement to an $\mathrm{RP}$ on a bridge or a driven stake or tree along the water's edge.

B. Estimate the depths and observe the velocity at 0.2 of the estimated depth. The meter should be at least 2.0 feet below the water surface. The actual depth the meter was placed below the water surface should be recorded in the notes. If an estimate of the depth is impossible just place the meter 2.0 feet below the water surface and observe the velocity there.

C. Make a complete measurement, including some vertical velocity curves, at a lower stage.

D. Use the complete measurement and difference in stage between the two measurements to determine the cross section of the first measurement.

E. Use vertical velocity curves to determine coefficients to adjust the velocities observed in step B to mean velocity.

F. Compute the measurement in the normal manner using the depths from step $\mathrm{D}$ and the velocities from step $\mathrm{E}$. 
4. The procedure to follow when measuring where it is impossible to keep the weight and meter in the water is:

A. Repeat step A in procedure 3.

B. Measure surface velocities by timing floating drift.

C. Repeat steps C, D, E, and F in procedure 3.

It should be remembered that just after the crest the amount of floating drift or ice will usually be greatly reduced and it may be possible to obtain velocity observations with a current meter. If this condition appears probable it would be best to omit the float measurement and make a current-meter measurement at a slightly lower stage.

5. During periods of rapidly changing stage, measurements should be made as quickly as possible to keep the change in stage to a minimum. The procedure to follow to speed up a measurement is:

A. Use the 0.6 depth method. The 0.2 depth method or the subsurface method could be used if placing the meter at the 0.6 depth creates vertical angles and thus wastes time because air and water depth corrections have to be made.

B. Reduce the velocity observation time to about $20-30$ seconds.

C. Reduce the number of sections taken to about 15-18.

By incorporating all three of the above practices a measurement very often can be made in 15 to 20 minutes. If the subsurface method for observing velocities is used, then some vertical velocity curves will be needed later to establish coefficients to convert observed velocity to mean velocity.
Anderson (1961) has shown that the discharge measurement error for a 45-second period of observation, the 0.2 depth and 0.8 depth method of velocity observation, and depth and velocity observed at 25 locations is 2.2 percent. This means that two-thirds of the measurements made using this procedure would be in error by 2.2 percent or less. Using Anderson's data, the error for a 25-second period of observation, the 0.6 depth method of velocity observation, and depth and velocity observed at 16 locations is 4.2 percent. This slight increase in error due to using the shortcut methods suggested in procedure (5) is more than offset by the reduction in accuracy that would be caused by excessive change in stage during the time required to make a normal measurement.

6. The procedure to follow if a series of measurements is wanted during a peak of short duration is:

A. Take about 10 sections.

B. Take velocity observations at $\mathbf{0 . 6}$ depth.

C. Repeat velocity and depth observations at the 10 sections as often as possible throughout the period of the flood wave.

D. Develop stage-velocity and stage-depth curves for each of the 10 sections.

E. Compute the discharge corresponding to any stage from the curves thus defined. 


\section{ALABAMA DISTRICT FLOOD PLAN - Appendix 5}

\section{EQUIPMENT REQUIREMENTS}

Current meters - Price AA (2)

Headphones (2)

Stop watches (2)

Tagline reel (Lee-Au $500 \mathrm{ft}$.)

Protractor

Reel (B56 or B50)

Spare cable and connector for reel

Sounding weight $(30 \mathrm{c}, 50 \mathrm{c}, 75 \mathrm{c}, 100 \mathrm{c})$

Spare hanger for reel

Weight pins (30c, 75c, 100c)

Tool box

Water-level measurement steel tape

Wading rod

Hip boots

Waders

Raincoat or rainsuit

Rainhat

Thermometer

Sample bottles

Life Jacket

Safety equipment for traffic
Flashlight

Camera

Stakes, nails, and flagging for high

water marks

Hatchet

Hand level

Rope

Flood note measurement sheets

Pencils

Calculator

Airline and wetline correction table

Current meter rating tables

Copy of district flood plan

Field folders

TWRI Book3, Chapter A8

Flood note measurement sheets

Pencils

Calculator

Airline and wetline correction table

Current meter rating tables

Copy of district flood plan

Field folders

TWRI Book3, Chapter A8 